\title{
Study of the seismic damage regularity of ancient masonry pagodas in the 2008 Wenchuan Earthquake
}

\author{
Y. Jianli \& L. Shengcai \\ Architectural Science and Engineering College, \\ Yangzhou University, China
}

\begin{abstract}
This paper investigates the characteristics and regularity of damage to ancient masonry pagodas in Sichuan province in high seismic intensity areas during the Wenchuan Earthquake by a statistic analyses method. Emphasizing the seismic damage of foundation and structural components of pagodas, the relation between seismic intensity and damage degree of pagodas is discussed. The analyses results indicated that masonry pagodas are hypersensitive to seismic action; the damage condition of pagodas are aggravated with the increase of seismic intensity, and the structural type, conformation character and site condition have a obvious influence on the degree of seismic damage of pagodas. Aiming at the three main damage characteristics, ground distortion, weak construction crack, and structural collapse, the typical cases are selected to demonstrate the regularity of seismic damage to ancient pagodas.
\end{abstract}

Keywords: ancient masonry pagoda, seismic intensity, site condition, construction characteristics, damage regularity.

\section{Introduction}

The ancient pagoda is a precious architectural heritage and with an important historical and art value. In the Wenchuan Earthquake of magnitude 8.0 on May $12^{\text {th }}, 2008$, a lot of pagodas in the high intensity regions of Sichuan province in China were severe damaged or collapsed, which aroused the extraordinary attention of the administrative departments and scholar community [1-4]. Based on the investigated data on pagodas in the Sichuan province, this paper analyzed the damage regularity of ancient pagodas in seismic intensity areas of VI degree 
to $\mathrm{X}$ degree during the Wenchuan Earthquake, discussed the influence of the ground condition, conformation character and structural type to damage degree of pagodas. Furthermore, aiming at the three main damage characteristics, ground distortion, weak conformation crack and structural collapse, the typical cases are selected to demonstrate seismic damage regularity of ancient pagodas.

\section{Basic information and definition on seismic damage of ancient pagodas}

There were a total of 61 pagodas in seismic intensity areas of VI to X degree during the Wenchuan Earthquake. The basic information of the pagodas is listed in Table 1, and Figure 1 shows the locations of the pagodas according to their serial number.

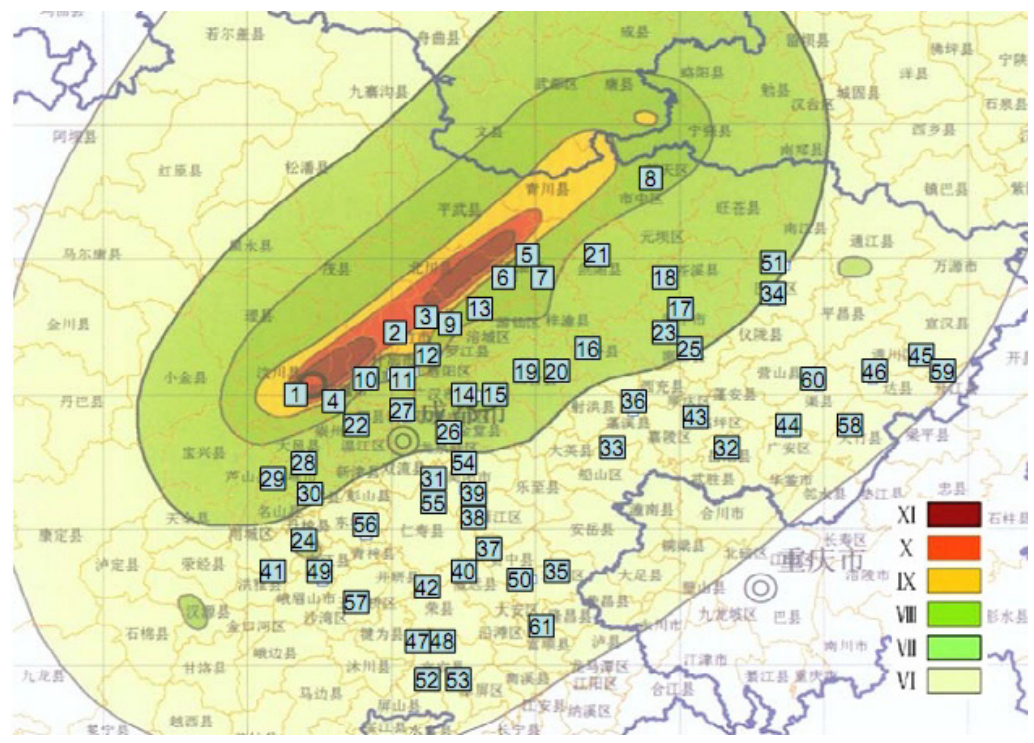

Figure 1: Intensity distribution and locations of pagodas in Sichuan province.

The classification information of pagodas is as follows: (1) Classification according to structural type: 34 pagodas belong to the multi-storey-pavilionstyle, 25 pagodas belong to the dense-Eaves-style, and 2 pagodas belong to the Vase-style. (2) Classification according to building material: 58 brick pagodas, 2 stone pagodas, and 1 adobe pagoda. (3) Classification according to construction field: 16 pagodas were built on flat ground, 5 pagodas were built on a riverside, 31 pagodas were built on a mountaintop, and 9 pagodas were built on a hillside.

To classify the seismic damage of pagodas reasonably, aiming at the repair demand of cultural heritage and the damage character of components of pagodas, the definition on grade and character of seismic damage of ancient pagodas is proposed (see Table 2). 
Table 1: $\quad$ Basic information of pagodas.

\begin{tabular}{|c|c|c|c|c|c|c|c|c|}
\hline $\begin{array}{l}\text { Seismic } \\
\text { intensity area }\end{array}$ & No. & $\begin{array}{l}\text { Name of } \\
\text { pagoda }\end{array}$ & $\begin{array}{l}\text { City or } \\
\text { county }\end{array}$ & $\begin{array}{l}\text { D. } \\
\text { G. }\end{array}$ & No. & $\begin{array}{l}\text { Name of } \\
\text { pagoda }\end{array}$ & $\begin{array}{l}\text { City or } \\
\text { county }\end{array}$ & $\begin{array}{l}\text { D. } \\
\text { G. }\end{array}$ \\
\hline$\geq X$ & 1 & Jionglan & Wenchuan & 5 & 2 & Wenfeng & Mianzhu & 5 \\
\hline IX & 3 & Wenxing & Anxian & 5 & 4 & Kuiguang & Dujiangyan & 4 \\
\hline \multirow{6}{*}{ VIII } & 5 & Nanyan & Jiangyou & 5 & 6 & Yunlong & Jiangyou & 4 \\
\hline & 7 & Nansan & Mianyang & 4 & 8 & Laiyan & Guangyuan & 4 \\
\hline & 9 & Longhu & Deyang & 4 & 10 & Zhengjuesi & Pengzhou & 4 \\
\hline & 11 & Yunjuyuan & Pengzhou & 4 & 12 & Zhenguosi & Pengzhou & 3 \\
\hline & 13 & Beita & Zhongjiang & 4 & 14 & Nanta & Zhongjiang & 3 \\
\hline & 15 & Feiying & Jiangyou & 3 & & & & \\
\hline \multirow{8}{*}{ VII } & 16 & Bita & Yantin & 4 & 17 & Baita & Langzhong & 4 \\
\hline & 18 & Chongxia & Cangxi & 4 & 19 & Beita & Santai & 4 \\
\hline & 20 & Donta & Santai & 4 & 21 & Beita & Jiange & 4 \\
\hline & 22 & Zikuta & Chongzhou & 3 & 23 & Shita & Langzhou & 3 \\
\hline & 24 & Baita & Danlun & 3 & 25 & Shenba & Nanbu & 3 \\
\hline & 26 & Ruiguang & Jintang & 3 & 27 & Baoguangsi & Xindu & 3 \\
\hline & 28 & Huilan & Qionlai & 2 & 29 & Shitasi & Qionlai & 2 \\
\hline & 30 & Fenweng & Pujiang & 2 & & & & \\
\hline \multirow{16}{*}{ VI } & 31 & Shengdesi & Jianyang & 3 & 32 & Baita & Yuechi & 3 \\
\hline & 33 & Shanji & Suining & 3 & 34 & Lingyuan & Bazhong & 3 \\
\hline & 35 & Sanyuan & Neijiang & 3 & 36 & Jiufengsi & Pengxi & 2 \\
\hline & 37 & Cangjie & Zizhong & 2 & 38 & Sanyuan & Zizhong & 2 \\
\hline & 39 & Baita & Ziyang & 2 & 40 & Baita & Weiyuan & 2 \\
\hline & 41 & Xiuwen & Hongya & 2 & 42 & Zhennan & Rounxian & 2 \\
\hline & 43 & Wuliang & Nanchong & 2 & 44 & Baita & Guangan & 2 \\
\hline & 45 & Baoquan & Kaijiang & 2 & 46 & Longzhua & Dazhou & 2 \\
\hline & 47 & Baita & Yibin & 2 & 48 & Heita & Yibin & 2 \\
\hline & 49 & Lingbao & Leshan & 2 & 50 & Gaosi & Neijiang & 2 \\
\hline & 51 & Buyue & Bazhong & 2 & 52 & Jiuzhou & Yibin & 1 \\
\hline & 53 & Dengying & Junlian & 1 & 54 & Hongbai & Jianyang & 1 \\
\hline & 55 & Timing & Jianyang & 1 & 56 & Dawansi & Meishan & 1 \\
\hline & 57 & Baita & Sanjiang & 1 & 58 & Wenfeng & Dazhu & 1 \\
\hline & 59 & Wenbi & Kaijiang & 1 & 60 & Wenfeng & Quxian & 1 \\
\hline & 61 & Jionglan & Fushun & 1 & & & & \\
\hline
\end{tabular}

Note: No. - Serial number of pagoda, DG - Damage grade of pagoda (see table 2). 
Table 2: Definition on grade and character of seismic damage of ancient pagodas.

\begin{tabular}{|l|l|l|l|}
\hline $\begin{array}{l}\text { Damage } \\
\text { grade }\end{array}$ & Damage degree & $\begin{array}{l}\text { Damage character of components } \\
\text { of pagoda }\end{array}$ & $\begin{array}{l}\text { Repair demand after } \\
\text { earthquake }\end{array}$ \\
\hline 1 & Slight damage & $\begin{array}{l}\text { Tiny cracks on tower body, or } \\
\text { slight damage on eaves or steeple }\end{array}$ & Minor repair \\
\hline 2 & Local damage & $\begin{array}{l}\text { Visible cracks on tower body, or } \\
\text { local break on eaves or steeple }\end{array}$ & Local repair \\
\hline 3 & Middling damage & $\begin{array}{l}\text { Obvious cracks on tower body, or } \\
\text { tower body light lean, or steeple } \\
\text { collapse }\end{array}$ & Major restoration \\
\hline 4 & Severe destruction & $\begin{array}{l}\text { Through cracks on tower body, or } \\
\text { tower body obvious lean, or } \\
\text { partial storey collapse }\end{array}$ & Whole restoration \\
\hline 5 & Whole destruction & Entire collapse of tower body & Reconstruction \\
\hline
\end{tabular}

\section{The relation between seismic intensity and damage degree of pagodas}

According to the definition of Table 2, the 61 pagodas are classified in five damaged conditions. The seismic intensity of every pagoda location is confirmed based on the "Seismic intensity distribution of the $M_{s} 8.0$ Wenchuan Earthquake". [5] The classification ratio of pagodas is list in Table 3.

Table 3: Classification ratio of seismic damage of pagodas in Sichuan province.

\begin{tabular}{|c|c|c|c|c|c|c|c|c|c|c|c|c|}
\hline \multirow{3}{*}{$\begin{array}{l}\text { Seismic } \\
\text { intensity } \\
\text { area }\end{array}$} & \multirow{3}{*}{$\begin{array}{l}\text { HPGA } \\
\left(\mathrm{m} / \mathrm{s}^{2}\right)[6]\end{array}$} & \multirow{3}{*}{$\begin{array}{l}\text { N. of } \\
\text { pagodas } \\
\text { in the } \\
\text { area }\end{array}$} & \multicolumn{10}{|c|}{ Damage degree } \\
\hline & & & \multicolumn{2}{|c|}{$\begin{array}{l}\text { Slight } \\
\text { damage }\end{array}$} & \multicolumn{2}{|c|}{$\begin{array}{l}\text { Local } \\
\text { damage }\end{array}$} & \multicolumn{2}{|c|}{$\begin{array}{l}\text { Middling } \\
\text { damage }\end{array}$} & \multicolumn{2}{|c|}{$\begin{array}{l}\text { Severe } \\
\text { destruction }\end{array}$} & \multicolumn{2}{|c|}{$\begin{array}{l}\text { Whole } \\
\text { destruction }\end{array}$} \\
\hline & & & N. & ratio & N. & ratio & N. & ratio & N. & ratio & N. & ratio \\
\hline VI & $0.45-0.89$ & 31 & 10 & $32 \%$ & 16 & $52 \%$ & 5 & $16 \%$ & & & & \\
\hline VII & $0.90-1.77$ & 15 & & & 3 & $20 \%$ & 6 & $40 \%$ & 6 & $40 \%$ & & \\
\hline VIII & $1.78-3.53$ & 11 & & & & & 3 & $27 \%$ & 7 & $64 \%$ & 1 & $9 \%$ \\
\hline IX & $3.54-7.07$ & 2 & & & & & & & 1 & $50 \%$ & 1 & $50 \%$ \\
\hline$\geq X$ & $\begin{array}{l}7.08- \\
14.14\end{array}$ & 2 & & & & & & & & & 2 & $100 \%$ \\
\hline \multicolumn{2}{|c|}{$\begin{array}{l}\text { Total number and } \\
\text { ratio of pagodas }\end{array}$} & 61 & 10 & $16 \%$ & 19 & $31 \%$ & 14 & $23 \%$ & 14 & $23 \%$ & 4 & $7 \%$ \\
\hline
\end{tabular}

Note: HPGA - horizontal peak ground acceleration.

From Table 3 we can find that the seismic damage degree of pagodas with increasing of seismic intensity tends to be serious, and there is a clear corresponding relation between the two. Be careful, the pagoda is very sensitive to earthquake action; there is a certain number of pagodas suffered middling damage in the seismic intensity area of VI degree. 


\section{Regularity of seismic damage of pagodas due to ground distortion}

\subsection{Statistical analysis of ground distortion damage of pagodas}

The masonry pagoda has a heavy deadweight, larger slenderness ratio and a relatively small foundation, which is sensitive to ground distortion caused by earthquakes. About 11 pagodas suffered seismic damage of ground distortion in the Wenchuan Earthquake, such as uneven subsidence of foundation or lean of tower body. Table 4 lists the construction site and slenderness ratio (H/D) of these pagodas, and classifies the damage of pagodas to the three conditions based on the degree of foundation subsidence or tower body lean.

Table 4: Classification of seismic damage of pagodas due to ground distortion.

\begin{tabular}{|c|c|c|c|c|c|c|c|}
\hline \multirow{3}{*}{$\begin{array}{l}\text { Seismic } \\
\text { intensity } \\
\text { area }\end{array}$} & \multirow{3}{*}{$\begin{array}{l}\text { Construction } \\
\text { site }\end{array}$} & \multicolumn{6}{|c|}{ Seismic damage condition of foundation or body of pagoda } \\
\hline & & \multicolumn{2}{|c|}{$\begin{array}{l}\text { Foundation } \\
\text { subsidence, tower } \\
\text { body crack }\end{array}$} & \multicolumn{2}{|c|}{$\begin{array}{l}\text { Foundation } \\
\text { subsidence, tower } \\
\text { body lean }\end{array}$} & \multicolumn{2}{|c|}{$\begin{array}{l}\text { Foundation serious } \\
\text { subsidence, tower } \\
\text { body serious lean }\end{array}$} \\
\hline & & $\begin{array}{l}\text { No. of } \\
\text { pagoda }\end{array}$ & $\mathrm{H} / \mathrm{D}$ & $\begin{array}{l}\text { No. of } \\
\text { pagoda }\end{array}$ & $\mathrm{H} / \mathrm{D}$ & $\begin{array}{l}\text { No. of } \\
\text { pagoda }\end{array}$ & $\mathrm{H} / \mathrm{D}$ \\
\hline \multirow[t]{2}{*}{ VI } & riverside & 44 & 4.3 & & & & \\
\hline & mountaintop & \begin{tabular}{|l|}
40 \\
38 \\
\end{tabular} & $\begin{array}{l}3.1 \\
4.5\end{array}$ & \begin{tabular}{|l|}
$\frac{32}{45}$ \\
44 \\
\end{tabular} & $\begin{array}{l}3.4 \\
4.1 \\
4.1\end{array}$ & 35 & 3.8 \\
\hline \multirow[t]{2}{*}{ VII } & riverside & & & 28 & 4.3 & 25 & 4.7 \\
\hline & mountaintop & & & & & 26 & 4.8 \\
\hline VIII & hillside & & & & & 11 & 4.0 \\
\hline
\end{tabular}

Note: $\mathrm{H}$ - highness of pagoda; $\mathrm{D}$ - subtense length of bottom of pagoda.

We can see from table 4: (1) The construction site conditions have an obvious influence on the seismic damage of ground distortion: a) The pagodas built on flat ground, no damage due to ground distortion; b) There are a total of 5 pagodas built on the riverside, and 3 pagodas with ground distortion, accounted for $60 \%$ of the total; c) There are a total 40 pagodas built on a mountaintop or hillside, and 8 pagodas with damage of ground distortion, accounted for $20 \%$ of the total. (2) The damage degree of ground distortion and slenderness ratio H/D of pagoda has some relevance; the slenderness ratio of all the 11 damaged pagodas is greater than 3.0, so it is easy to aggravate the inclined degree of the pagoda in the uneven settlement condition of foundations. (3) The damage degree of ground distortion increases with increasing seismic intensity, and has led to serious deformation of the upper structure. Note, that there are 3 pagodas with serious damage due to the failure of foundation in the seismic intensity area of VI and VII degrees. 


\subsection{Typical pagodas with a serious lean due to ground distortion}

\subsubsection{Shenba pagoda in Nanbu County}

Shenba pagoda is a 7-storey hexagonal multi-storey-pavilion brick tower, 14 meters high. The pagoda is located in the inundated area of a lake for a flood reservoir, and the foundation is damaged by a change in water level. During the Wenchuan Earthquake, the foundation of the pagoda was subsidence, and led to a serious tilt of the tower body (Fig. 2).

\subsubsection{Sanyuan pagoda in Neijiang City}

Sanyuan Pagoda is a 10-storey octagonal multi-storey -pavilion brick tower, 62.7 meters high. The pagoda is located on the top of San-yuan Mountain, shrubs and weeds growing into the brick joints resulted in cracking and an incline of the foundation. The seismic action of the Wenchuan Earthquake aggravated the inclined condition of San-yuan pagoda. According to the measure of global positioning system, the top displacement value is 0.631 meters and the deviation angle is $14^{\circ} 41^{\prime} 50^{\prime \prime}$, so this pagoda has been identified as a dangerous tower (Fig. 3).

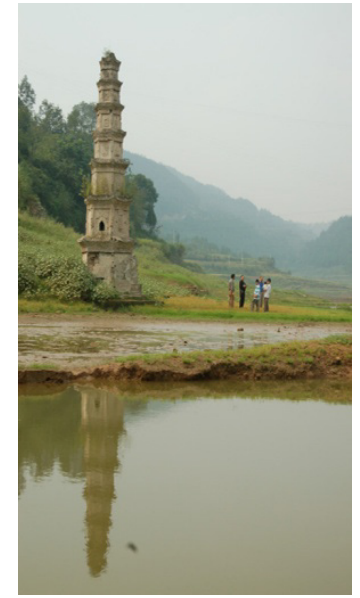

Figure 2: Shenba pagoda.

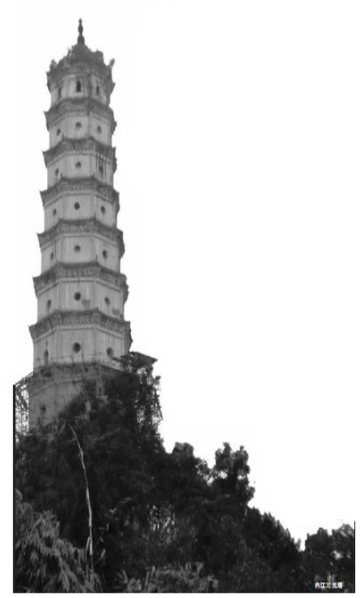

Figure 3: Sanyuan pagoda.

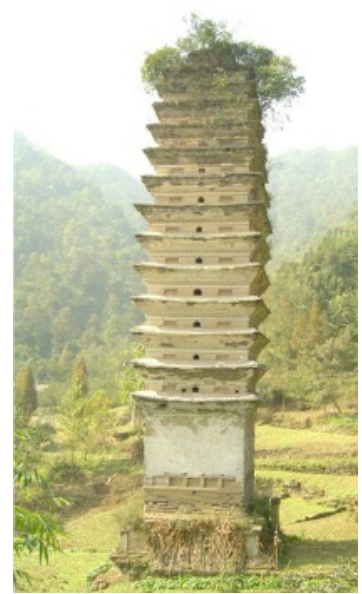

Figure 4: Yunjuyuan pagoda.

\subsubsection{Yunjuyuan pagoda in Penzhou City}

Yunjuyuan pagoda is a 13-storey square Dense-eaves brick tower, 20.9 meters high. The pagoda is located on the hillside of a mountain and the foundation had been damaged by long-term soil and water loss before the Wenchuan Earthquake. The Wenchuan Earthquake led to the serious displacement of the foundation, and the tower body tilted about $10 \mathrm{~cm}$; obvious cracks appeared (Fig. 4). 


\section{Regularity of seismic damage of pagodas due to weak conformation}

\subsection{Statistical analysis of weak conformation damage of pagodas}

Because of the low tensile strength of masonry, the weak part of the tower body easily cracks under the tension resulting from an earthquake. For the pagoda with a string of door holes set up in the same position of each storey, the wall between the upper and lower holes is a weak part and it is easy to produce shear deformation leading to vertical splitting of the wall under earthquake action.

In the Wenchuan Earthquake, about 20 pagodas belong to the damage type of masonry wall cracking. Among them, 8 pagodas suffered a masonry split along the vertical opening walls. These pagodas with split damage are list in table 5 . The cracking conditions of wall are classified into three types, and the vertical opening state of the wall is also listed as a reference.

Table 5 shows: (1) the cracking degree of the tower body increases with the increase of seismic intensity. (2) The door holes along the vertical tower body form a weak conformation, and the wall with a string of door holes is the main reason for a through split of the tower body.

Table 5: Classification of seismic damage due to weak conformation.

\begin{tabular}{|c|c|c|c|c|c|c|c|}
\hline \multirow{3}{*}{$\begin{array}{l}\text { Seismic } \\
\text { intensity } \\
\text { area }\end{array}$} & \multirow{3}{*}{$\begin{array}{l}\text { Construction } \\
\text { site }\end{array}$} & \multicolumn{6}{|c|}{ Cracking conditions of the wall } \\
\hline & & \multicolumn{2}{|c|}{ Local cracking } & \multicolumn{2}{|c|}{ Serious cracking } & \multicolumn{2}{|c|}{ Through split } \\
\hline & & $\begin{array}{l}\text { No. of } \\
\text { pagoda }\end{array}$ & $\begin{array}{l}\text { Opening } \\
\text { state }\end{array}$ & $\begin{array}{l}\text { No. of } \\
\text { pagoda }\end{array}$ & $\begin{array}{l}\text { Opening } \\
\text { state }\end{array}$ & $\begin{array}{l}\text { No. of } \\
\text { pagoda }\end{array}$ & $\begin{array}{l}\text { Opening } \\
\text { state }\end{array}$ \\
\hline \multirow[t]{2}{*}{ VI } & flat ground & 31 & A & & & & \\
\hline & mountaintop & & & 34 & A & & \\
\hline VII & flat ground & & & $\frac{27}{24}$ & $\begin{array}{l}\text { C } \\
\text { B }\end{array}$ & & \\
\hline VIII & mountaintop & & & 12 & $\overline{\mathrm{A}}$ & \begin{tabular}{|l|}
10 \\
9
\end{tabular} & $\begin{array}{l}\mathrm{A} \\
\mathrm{A}\end{array}$ \\
\hline IX & flat ground & & & & & 4 & A \\
\hline
\end{tabular}

Note: The vertical opening state of the wall : A - door hole set on every storey; B - door hole and blind hole set on the storey alternately; $\mathrm{C}$ - blind hole set on every storey.

\subsection{The typical pagodas with vertical split due to weak conformation}

\subsubsection{Kuiguang pagoda in Dujiangyan City}

Kuiguang pagoda is a 17 -storey hexagonal multi-storey-pavilion brick tower, 52.7 meters high. The door holes are set up in the same position of each storey (Fig. 5). During the Wenchuan Earthquake, the wall cracked thoroughly from the fifth storey to the top on the southwest and northeast sides of the tower body, the maximum crack width is $15 \mathrm{~cm}$. 


\subsubsection{Lonhu pagoda in Deyang City}

Lonhu pagoda is a 13-storey square dense-eaves brick tower, 37.8 meters high. During the Wenchuan Earthquake, on the north and south sides of the tower body the through cracks appeared from the bottom to the top along the vertical midline of the wall. The cracks split the tower body into two parts, leading to the destruction of the structure (Fig. 6).

\subsubsection{Zhengjuesi pagoda in Pengzhou City}

Zhengjuesi pagoda is a 13-storey square dense-eaves brick tower, 27.54 meters high. Under the seismic action of the Wenchuan Earthquake, visible cracks appeared on the four sides of tower body. On the west side of the tower body, a through crack of about $5 \mathrm{~cm}$ in width appeared along the vertical midline extending from the upside of the arch to the top of the tower (Fig. 7).

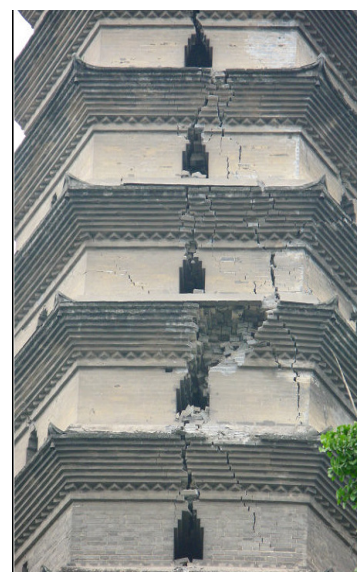

Figure 5: Kuiguang pagoda.

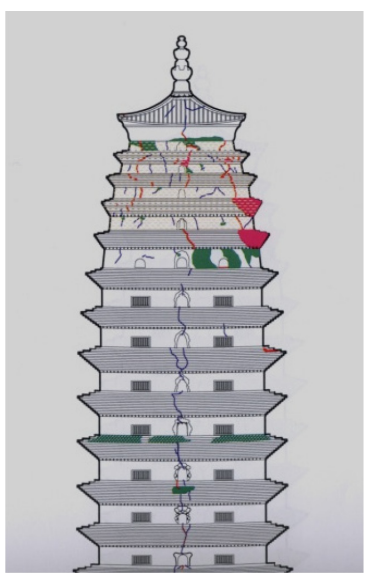

Figure 6: Lonhu pagoda.

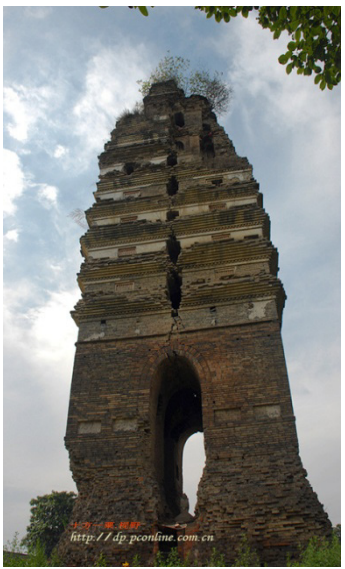

Figure 7: Zhengjuesi pagoda.

\section{Regularity of seismic damage of pagodas due to insufficient structural stiffness}

\subsection{Statistical analysis of structural failure of pagodas}

The pagodas in the earthquake disaster area in the Sichuan province can be classified into two main structural types; the multi-storey-pavilion pagoda and the dense-eaves pagoda. In general, the dense-eaves pagoda cannot climb inside, because the inner space is filled with brick and rammed clay. The multi-storeypavilion pagoda usually can climb to the top, it with a big inner space, so the structural stiffness is smaller than that of the dense-eaves pagoda. For the pagoda with a larger slenderness ratio $\mathrm{H} / \mathrm{D}$ and smaller structural stiffness, under the strong earthquake action, the tower body is easy to form large lateral displacement and cause break or collapse. 
There are a total of 14 pagodas which collapsed, partly or completely, in the Wenchuan Earthquake. Table 6 lists the names and construction sites of the pagodas, including their slenderness ratio H/D and structural type as a reference.

Table 6 shows: (1) Pagodas with structural failure where the slenderness ratio $\mathrm{H} / \mathrm{D}$ is more than 3 , the greater the slenderness ratio, the more serious the collapse. (2) From the point of view of structural type, the damage degree of the multi-storey-pavilion pagoda is serious; it is more obvious in the seismic intensity VII and VIII areas. The reason for this is the wall of the pavilion-style pagoda is relatively thin and the spatial stiffness is relatively small. (3) The collapse degree of the tower body increases with the increase of seismic intensity, and the mountain height has a significant amplifying effect on the action of the earthquake; in the seismic intensity VII and VIII areas, pagodas built on a mountaintop had a higher collapse ratio. Notable is, 7 pagodas suffered partial collapse in the seismic intensity area of VII degree, which indicates that the earthquake effects serious damage on pagodas.

Table 6: Classification of seismic damage due to insufficient structural stiffness.

\begin{tabular}{|c|c|c|c|c|c|c|c|c|}
\hline \multirow{3}{*}{$\begin{array}{l}\text { Seismic } \\
\text { intensity } \\
\text { area }\end{array}$} & \multirow{3}{*}{$\begin{array}{l}\text { Construction } \\
\text { site }\end{array}$} & \multicolumn{7}{|c|}{ Damage condition of tower body } \\
\hline & & \multicolumn{4}{|c|}{ Collapse partly } & \multicolumn{3}{|c|}{ Collapse completely } \\
\hline & & $\begin{array}{l}\text { No. of } \\
\text { pagoda }\end{array}$ & $\begin{array}{l}\text { Collapsed } \\
\text { storeys / } \\
\text { total storeys }\end{array}$ & $\mathrm{H} / \mathrm{D}$ & $\begin{array}{l}\text { Structural } \\
\text { type }\end{array}$ & $\begin{array}{l}\text { No. of } \\
\text { pagoda }\end{array}$ & & $\begin{array}{l}\text { Structural } \\
\text { type }\end{array}$ \\
\hline \multirow[t]{2}{*}{ VII } & flat ground & 16 & $5 / 7$ & 3.5 & A & & & \\
\hline & mountaintop & \begin{tabular}{|l|}
$\frac{18}{19}$ \\
$\frac{20}{21}$ \\
17 \\
\end{tabular} & \begin{tabular}{|l|}
$3 / 9$ \\
$4 / 9$ \\
$4 / 9$ \\
$4 / 7$ \\
$7 / 13$
\end{tabular} & \begin{tabular}{|l|}
4.4 \\
3.0 \\
3.5 \\
3.7 \\
3.9
\end{tabular} & $\begin{array}{l}\mathrm{A} \\
\mathrm{A} \\
\mathrm{A} \\
\mathrm{A} \\
\mathrm{A}\end{array}$ & & & \\
\hline VIII & mountaintop & \begin{tabular}{|l|}
13 \\
7 \\
6 \\
8 \\
\end{tabular} & \begin{tabular}{|l|}
$3 / 13$ \\
$4 / 9$ \\
$7 / 9$ \\
$7 / 13$
\end{tabular} & \begin{tabular}{|l|}
3.0 \\
3.1 \\
3.1 \\
5.3
\end{tabular} & $\begin{array}{l}\mathrm{B} \\
\mathrm{A} \\
\mathrm{A} \\
\mathrm{A}\end{array}$ & 5 & 2.8 & $\mathrm{C}$ \\
\hline IX & flat ground & & & & & 3 & 3.1 & A \\
\hline \multirow[t]{2}{*}{$\geq \mathrm{X}$} & flat ground & & & & & 2 & 5.5 & B \\
\hline & riverside & & & & & 1 & 4.7 & B \\
\hline
\end{tabular}

Note: Structural type of pagoda: A - multi-storey-pavilion style; B - dense-eaves style; C-vase style.

\subsection{Typical pagodas with serious collapse due to insufficient structural stiffness}

\subsubsection{Bita pagoda in Yantin County}

Bita pagoda is a 7-storey hexagonal multi-storey-pavilion brick tower, 31 meters high. The pagoda is located in a seismic intensity area of VII degree and the 
construction site is flat ground. However, the upper five storeys have collapsed, with only the 9-meter high bottom storey remaining (Fig. 8). Testing after the Wenchuan Earthquake shows that the material strength of the pagoda is low and the masonry quality is poor. The niches weakened the structural stiffness of the thin wall, leading to the deficiency in seismic performance of the overall structure.
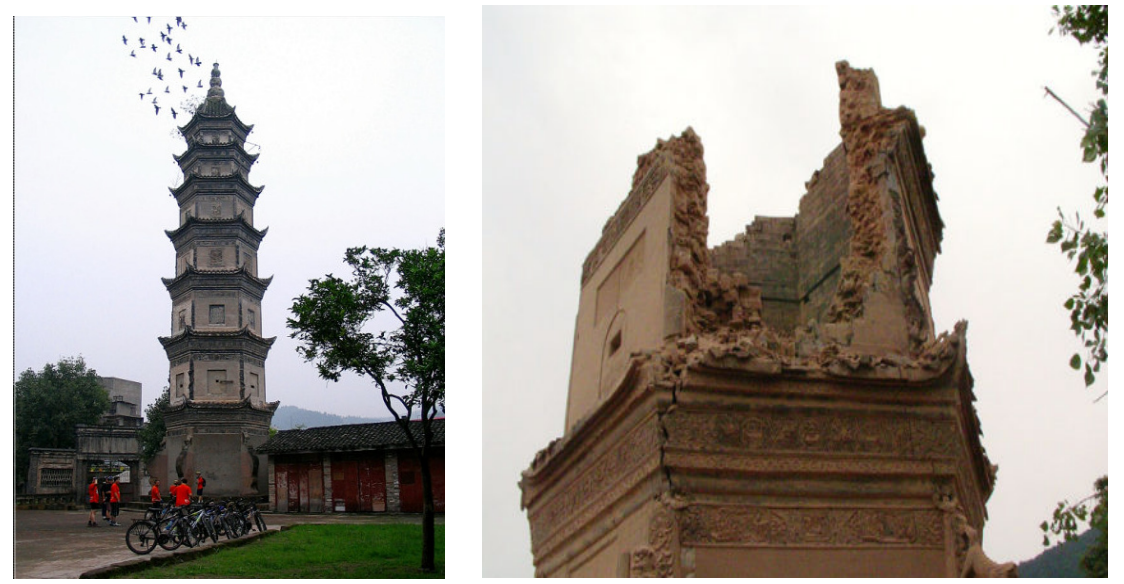

Figure 8: Bita pagoda (left: before the earthquake; right: after the earthquake).
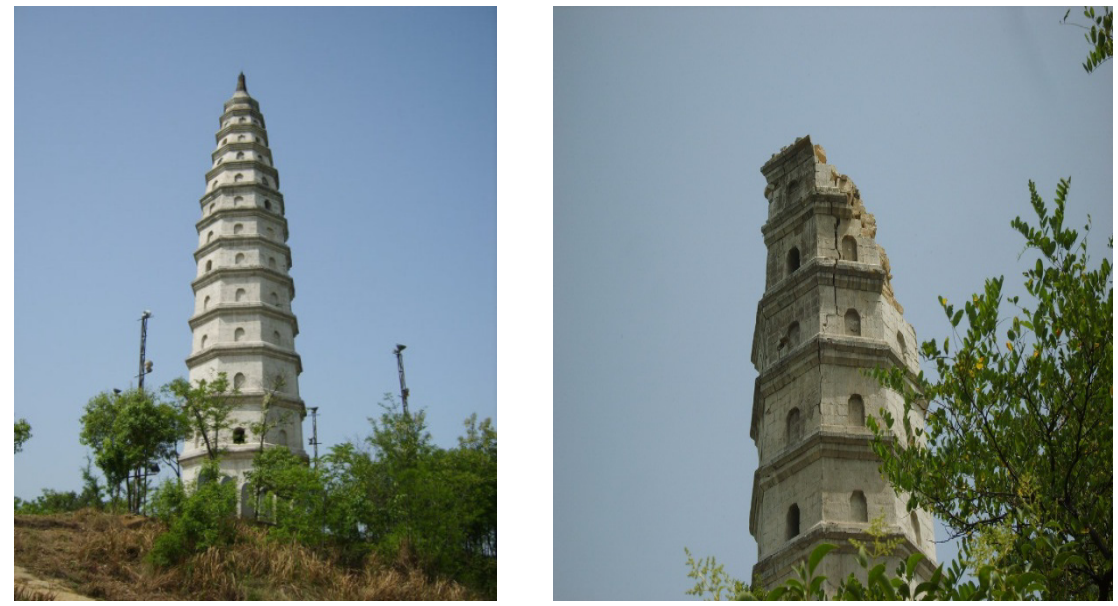

Figure 9: Laiyan pagoda (left: before the earthquake; right: after the earthquake).

\subsubsection{Laiyan pagoda in Guangyuan City}

Laiyan pagoda is a 13-storey octagonal multi-storey-pavilion brick tower, 36 meters high. When the Wenchuan Earthquake took place on May $12^{\text {th }}, 2008$, the 
$8^{\text {th }}$ storey to the top of the tower body collapsed at once. After that, a lot of aftershocks took place on May $25^{\text {th }}$ to $27^{\text {th }}$ in Qingchuan County and Ningqiang County, which led to the Laiyan pagoda being damaged again and the $6^{\text {th }}$ and $7^{\text {th }}$ storeys also collapsed (Fig. 9). Analysis shows that, Laiyan pagoda, being built on a mountaintop, its slenderness ratio H/D of 5.3, the amplifying effect of the mountain height on the action of the earthquake as well as the large slenderness ratio of the tower, are the important factors of pagoda collapse.

\subsubsection{Wenxing pagoda in Anxian County}

Wenxing pagoda is a 13-storey square multi-storey-pavilion adobe brick tower, 28 meters high; the first storey with a lower stone base and the remaining 12 storeys built from adobe brick. Its unique architectural materials and construction pattern are no longer seen in existing pagodas. The adobe brick is made from hemp, grass fibre and clay, with the mortar using sand, clay and a glutinous rice paste mixture, so the structural integrity of masonry tower is not high. Following up to IX degree seismic intensity in the region, the strong earthquakes led to this adobe tower collapsing entirely, with only the bottom, about 6 meters high, remaining (Fig. 10).
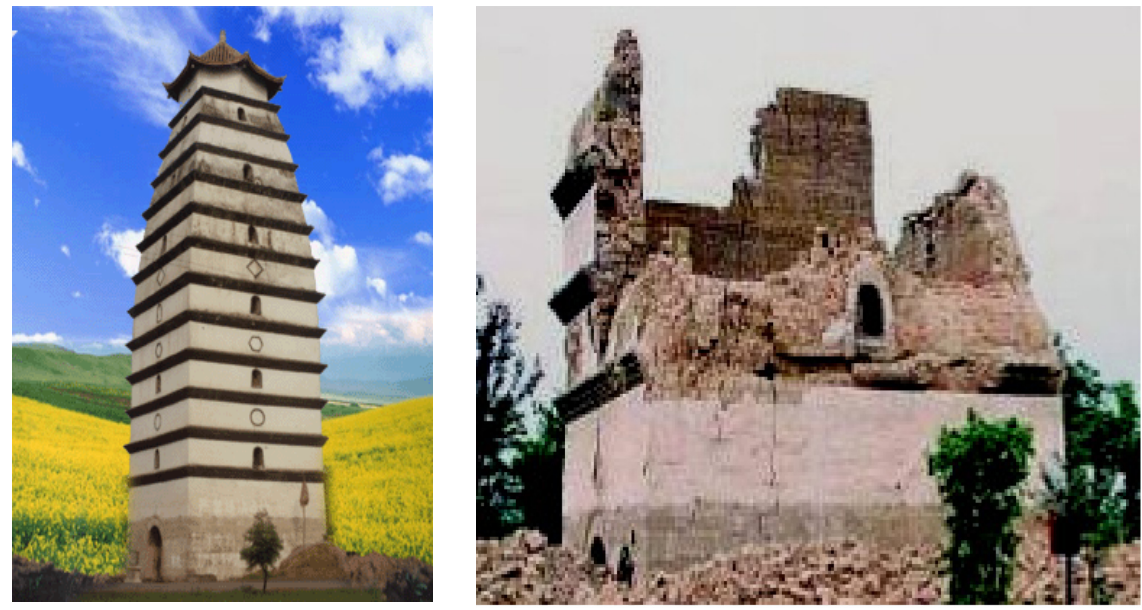

Figure 10: Wenxing pagoda: (left: before the earthquake; right: after the earthquake).

\section{Conclusion and suggestion}

The damaged pagodas in the Wenchuan Earthquake are an important resource on the research of ancient architecture protection. Based on the data collection and field investigation, this paper discussed the damage regularity of ancient masonry pagodas, analyzed the relationship between the seismic intensity and damage degree of pagodas. Research shows that: (1) the damage degree of pagodas with the increasing of the seismic intensity tends to be serious; both 
have a clear corresponding relationship. (2) The pagoda is very sensitive to the construction site condition; for the pagoda built on the riverside or mountaintop, the prevention of foundation seismic damage needs to be strengthened. (3) The structural type and conformation characteristics of the pagoda have a great influence on the damage degree; for the pagoda with a string of door holes set at the same position of each storey, attention needs to be paid to the identification of splitting resistance of the tower body; in addition, for the multi-storeypavilion pagoda where the slenderness ratio H/D is larger than 3, and which is located in an area of seismic intensity equal or greater than VII degrees, attention needs to be paid to the evaluation of structural collapse resistance.

\section{Acknowledgements}

This research is supported by the National Natural Science Foundation of China (51078323).

The Cultural Heritage Administration of Sichuan Province is gratefully acknowledged for their help in the investigation of pagodas.

\section{References}

[1] State Cultural Relic Bureau, National plan for rebuilding after Wenchuan Earthquake, save, protection and restoration for cultural relics [M], Beijing: Cultural Relic Press, 2008 (in Chinese)

[2] Cultural Relic Bureau of Sichuan Province, Brief introduction on damaged cultural relics in Sichuan province $[\mathrm{J}]$, Journal of literature and history, 2008(4): 24-35 (in Chinese)

[3] Sichuan Institute of Historic Relic Archaeology and Research, Investigation report on damaged cultural relics in Sichuan province in Wenchuan earthquake [J], Sichuan Cultural Relics, 2008(4): 3-10 (in Chinese)

[4] Yuan Jianli, Seismic damage characters and appraisal method of ancient masonry pagodas, "Investigation on seismic damage of buildings in Wenchuan earthquake" [C], Beijing: China Architecture \& Building Press, Oct. 2008: 396-403 (in Chinese)

[5] Seismic intensity distribution of the $M_{s} 8.0$ Wenchuan Earthquake [M], Earthquake information web of China, Aug. 2008 (in Chinese)

[6] National Standard of P.R. of China, GB/T 17742-2008, The Chinese Seismic Intensity Scale [S], Beijing: Standards Press of China, 2009 (in Chinese) 